\title{
Uprostorivanje seksualne $\mathbf{i}$ rodne različitosti u odgojno-obrazovnim ustanovama
}

\author{
Marija Bartulović \\ Filozofski fakultet Sveučilišta u Zagrebu, Hrvatska \\ e-mail: mbartulo@ffzg.hr
}

\author{
Barbara Kušević \\ Filozofski fakultet Sveučilišta u Zagrebu, Hrvatska \\ e-mail:bkusevic@ffzg.hr
}

SAŽETAK Cilj je ovoga rada prikazati različite načine prostornoga posredovanja seksualne i rodne različitosti u odgojno-obrazovnim ustanovama. Prvi dio donosi pregled terminoloških polazišta rada, razmatrajući koncepte geografije obrazovanja i integralnosti sintagme seksualne i rodne različitosti, dok drugi dio seksualnost i rod smješta u odgojno-obrazovnu ustanovu i analizira različite aspekte njihova uprostorivanja, stavljajući naglasak na tlocrt i materijalno uređenje odgojno-obrazovnih ustanova te na materijale posredovane odgojno-obrazovnim procesom. Zaključni dio rada promišlja o mogućnostima daljnjih modaliteta istraživanja ove teme.

Ključne riječi: geografija obrazovanja, prostorno-materijalno okruženje odgojno-obrazovne ustanove, heteronormativnost, rodna binarnost, inkluzivnost odgojno-obrazovnoga procesa.

Copyright (C) 2020 Institut za društvena istraživanja u Zagrebu - Institute for Social Research in Zagreb Sva prava pridržana - All rights reserved 


\section{Uvod ${ }^{1}$}

Društvene znanosti dugo je vremena obilježavala određena razina tabuiziranosti tema roda i seksualnosti. Govoreći o pedagogiji, takav je njen odnos prema tim temama povezan s nesklonošću smještanja seksualnosti u kontekst djetinjstva ${ }^{2}$ (Stone, Ingham i Gibbins, 2013., prema Robinson, Smith i Davies, 2017.). Ipak, posljednjih nekoliko desetaka godina u području odgoja i obrazovanja raste broj istraživanja usmjerenih na analizu odgojno-obrazovnih ustanova kao mjesta konstrukcije seksualnih i rodnih identiteta učenika, odnosno na "službenu kulturu školovanja i načine kako prakse poput kurikuluma i pedagoških interakcija konstituiraju specifična seksualna značenja i identitete" (Alldred i David, 2007.; DePalma i Atkinson, 2009.; Kehily, 2002.; Measor, Tiffin i Miller; 2000.; sve prema Allen, 2013.:57). Jednako kao rod i seksualnost, i prostorna dimenzija odgojno-obrazovnoga procesa već je dulje vrijeme tematizirana u nekim pedagogijskim disciplinama, u kojima je prostor dobio ulogu trećega odgajatelja (Rinaldi, 2006.), dominantno usmjerenoga na oblikovanje prostorno-materijalnoga okruženja podržavajućega za holistički razvoj djeteta. Iako je u pozadini te usmjerenosti shvaćanje prostora kao procesne materijalnosti, odnosno entiteta "u permanentnome stanju nastajanja, akcije prije no lokacije, koji [prostor] se oblikuje i preoblikuje (i ponekad raščinjava)" (Crang, 2005., prema Allen, 2013.:61), pregled literature ukazuje na to da je dimenzija roda, a osobito seksualnosti, dugo bila stavljana na margine promišljanja o prostornoj dinamici odgojno-obrazovnih ustanova. To se promijenilo tek početkom ovoga stoljeća, kada su geografi pokazali pojačan interes za svakodnevne prostore školovanja i obrazovanja (npr. Collins i Coleman, 2008.; Cook, Phillips i Holden, 2006.; Evans, 2006.; Fielding, 2000.; Hemming, 2007.; Holloway, Hubbard, Jöns i Pimlott-Wilson, 2010.; Holloway i Valentine, 2003.; Hyams, 2000.). To je uključivalo odmak od tradicionalnoga poimanja odgojno-obrazovnih ustanova i alternativno jače usmjeravanje na njihove institucijske geografije i društveno-prostorne procese koji unutar njih dobivaju oblik (Cook i Hemming, 2011.:1). Takvo je razumijevanje prostora u skladu s teorijskim stremljenjima u suvremenoj sociologiji, koja prostor promatra kao kompleksnu mrežu materijalnih, društvenih i simboličkih dimenzija, apostrofirajući upravo relacijski element konstituiranja prostora (Löw, 2016.). Takvo nas shvaćanje prostora upućuje na manjkavost svake analize koja bi odgojno-obrazovnim ustanovama pristupala kao izoliranim entitetima, odijeljenima od širega društvenog konteksta, te u obzir ne bi uzimala opću društvenu klimu spram seksualne i rodne različitosti. $\mathrm{Na}$ tome je tragu i cilj ovoga rada, koji je prikazati ra-

\footnotetext{
1 Rad je nastao temeljem izlaganja (Prema interkulturnoj odgojno-obrazovnoj ustanovi: pedagogično pristupanje rodnoj i seksualnoj različitosti) na znanstveno-stručnoj konferenciji Pedagogija i interdisciplinarnost, koja je u organizaciji Hrvatskoga pedagogijskog društva i Filozofskoga fakulteta Sveučilišta u Zagrebu održana u lipnju 2019. godine.

2 Koliko tema različitosti seksualnih i rodnih identiteta postaje kontroverznom kada biva smještenom u kontekst ustanova ranoga i predškolskoga odgoja, čak i kada je medij toga smještanja slikovnica, pokazuju recentne polemike koje je izazvalo izdavanje prve slikovnice na hrvatskome jeziku o duginim obiteljima.
} 
zličite načine prostornoga posredovanja seksualne i rodne različitosti u odgojno-obrazovnim ustanovama.

\section{Terminološka polazišta rada}

Terminološki okvir rada čini sintagma rodne i seksualne različitosti, koju ovdje, u maniri shvaćanja teorije kao mogućnosti, usmjerene $\mathrm{k}$ destabilizaciji i propitivanju uvriježenih pretpostavki (Gulson i Symes, 2007.), ne smatramo konstruktivnim precizno definirati, već inzistiramo na njenome queer potencijalu protivljenja binarnoj logici (muško/žensko, heteroseksualno/homoseksualno) i prepoznavanja ograničenja te binarnosti (Willis, 2017.). Krećući se unutar tih koordinata i shvaćajući rod i seksualnost kao dimenzije koje se neodvojivo prožimaju, pod sintagmom rodne i seksualne različitosti podrazumijevamo konstitutivni karakter roda i seksualnosti za čovjeka kao biće, koji uključuje promišljanje i analizu beskrajnoga mnoštva interakcija između pojedinca i svijeta, u kojima on biva konstituiran i konstruiran kao rodno i seksualno biće. Smjestimo li to u kontekst odgoja i obrazovanja, pažnju ćemo usmjeriti na načine na koje odgojno-obrazovne ustanove sudjeluju u konstrukciji rodnoga i seksualnoga identiteta učenika, u perpetuiranju heteronormativnosti društva i njegove rodno-binarne normativnosti, kao i načine na koje kategorije roda i seksualnosti izmiču definitivnoj odredivosti.

Promišljanju o tim temama nastojale smo pristupiti iz pedagogijske perspektive, no znanstveni tekstovi iz područja pedagogije koji se bave seksualnosti nerijetko nude definicije seksualnosti koje su nastale u drugim znanstvenim disciplinama, prije svega medicini i sociologiji, ili su derivirane iz ljudsko-pravne domene (što osobito vrijedi za operacionalizaciju seksualne i rodne različitosti). U traganju za pedagogijskim pogledom na seksualnost poslužio nam je Sielertov (2008.) Uvod u seksualnu pedagogiju, koji, u nastojanju da se odmakne od medicinsko-pravnih definicija, seksualnost određuje kao opću, prema užitku usmjerenu životnu energiju, koja se ne može odvojiti od cjelokupne čovjekove ličnosti; koja se služi tijelom (ne može se zamisliti bez tijela); koja se napaja iz mnogih izvora (kako iz kulturnih utjecaja tako iz procesa učenja); koja je na različite načine smislena (osim produžetka vrste, smisao ima u užitku samome, u zasnivanju identiteta, odnosa i sl.) i koja posjeduje posve različite oblike izražavanja (izražavanje naše seksualnosti ne može se svesti na domenu seksualnoga čina, već je ona kao integralni dio čovjekova identiteta prisutna u svakom našem djelovanju). Njegovu definiciju seksualnosti navodimo jer nudi dobru platformu za dekonstrukciju svođenja seksualnosti na funkciju produljenja vrste, kao i zbog autorova poziva na promišljanje o obrazovljivosti seksualnosti, koji ponuđena operacionalizacija gotovo u svim dimenzijama implicira.

Slijedeći Sielertovu perspektivu, ovaj rad smještamo na intersekciju kritičkoga pedagogijskog pristupa seksualnosti i sada već tradicije mišljenja o odnosu obrazovanja i 
prostora, koja se u tekstovima različitih autora različito naziva, pa tako Gruenewald (2003.) piše o kritičkoj pedagogiji mjesta, Taylor (2009.) o geografiji obrazovanja, a Allen (2013.) o seksualnoj geografiji školovanja. U pregledu te tradicije mišljenja, koju ćemo u nastavku teksta zvati geografijom obrazovanja, Cook i Hemming (2011.) ističu tri centralne okosnice teorijskih i empirijskih istraživanja usmjerenih na različite načine na koje prostor u odgojno-obrazovnim procesima istovremeno konstruira i biva konstruiran. Prva je od njih ljudsko tijelo, koje "može biti promatrano i kao entitet u prostoru i kao društveni prostor po sebi. Tijelo može biti shvaćeno kao granica između sebe i drugih, mjesto doživljavanja emocija, mjesto konstituiranja osobnih i društvenih identiteta ili kao mjesto borbe i otpora (Valentine, 2001.)" (prema Cook i Hemming, 2011.:3). Druga centralna tema odnosi se na fizičku, društvenu i kulturnu dimenziju prostora, pri čemu se fizička odnosi na materijalnu realnost, dok se ostale dvije očituju u idejama, simbolima i konceptima, koji čine alat za osmišljavanje i izražavanje mogućnosti ljudskoga djelovanja (Knott, 2005., prema Cook i Hemming, 2011.). Treća se centralna tema odnosi na aktivnu dimenziju prostora, odnosno činjenicu da je prostor "više nego tek površina na kojoj se odvijaju temporalni procesi, već je zapravo produkt društvenih odnosa i praksi. On je uvijek u procesu nastajanja i stoga uvijek nedovršen” (Massey, 1999., prema Cook i Hemming, 2011.:4). U sljedećoj cjelini, u kojoj ćemo seksualnost i rod smjestiti u odgojno-obrazovnu ustanovu, vraćat ćemo se na te bitne dimenzije tjelesnosti, višedimenzionalnosti i procesnosti prostora.

U daljnjoj ćemo se razradi teksta, kao i u našemu svakodnevnome djelovanju, voditi temeljnim postavkama feminističke i kritičke pedagogije, koje svrhu obrazovanja vide u uočavanju, analizi i transformaciji nepravednih i porobljujućih aspekata toga procesa, odnosno ciljem obrazovanja vide stvaranje boljeg i pravednijeg društva, temeljni alat za što čini proces konscijentizacije (Freire, 2002.) svih njegovih članova. Produktivnost spajanja tih dviju srodnih teorijskih perspektiva demonstrira Shapiro (2015.) konstituiranjem kritičke pedagogije tijela, otvarajući dijalog između klasičnih kritičkih pedagoga kao što su Paul Freire i Peter McLaren te feminističkih autorica kao što su Maxine Green i Kathleen Weiler. U ovome radu taj dijalog smještamo u kontekst geografije obrazovanja, oslanjajući se pritom na Gruenewalda (2003.), koji svoju kritičku geografiju prostora gradi na dvama konceptima bliskima kritičkoj pedagogiji, dekolonizaciji i reinhabitaciji. Dekolonizacija je nasljeđe kritičke pedagogije koje se odnosi na identificiranje i mijenjanje za ljude i prostor porobljujućih načina mišljenja (Gruenewald, 2003.). "Iz odgojno-obrazovne perspektive, ona [dekolonizacija] znači odučavanje od mnogo toga što dominantna kultura i školovanje poučavaju, i učenje više društveno pravednih i ekološki održivih načina bivanja u svijetu." (Gruenewald, 2003.:9) Pod reinhabitacijom autor podrazumijeva "identificiranje, obnavljanje i kreiranje materijalnih prostora i mjesta koja nas uče kako u svome sveukupnom okruženju živjeti dobro" (Gruenewald, 2003.:9). Koristeći se autorovim konceptima, u nastavku rada nastojat ćemo dekolonizirati i reinhabitirati seksualnost i rod u odgojno-obrazovnome prostoru. Svjesne smo, međutim, ozbiljnosti Taylorove (2009.) konstatacije 
da je za produktivan odnos pedagogije i geografije nedovoljno korištenje vokabulara geografije u obrazovanju, što Robertson (2009., prema Taylor, 2009.) naziva fetišiziranjem prostora, već se $s$ razine fluentnosti u vokabularu geografije (npr. uvođenjem riječi kao što su prostorno-materijalno okruženje, arhitektura odnosa i sl.) valja pomaknuti prema "njegovanju tacitnoga znanja koje omogućuje prakticiranje ili ‘činjenje' geografije” (npr. razumijevanjem dalekosežnih pedagogijskih implikacija odvojene nastave tjelesnoga odgoja i obrazovanja za djevojčice i dječake (Taylor, 2009.:652; primjeri naši), što je pomak koji nastojimo napraviti u nastavku rada.

\section{Smještanje seksualnosti i roda u odgojno-obrazovnu ustanovu}

Nova sociologija djetinjstva oblikovala je novi pogled na djetinjstvo, koje se danas promatra kao diversificirani društveni konstrukt oslobođen univerzalnih zakonitosti dječjega razvoja, zamijenjenih, kako Bašić (2011.) ističe, individualiziranjem i akceleriranjem razvoja i rastućom važnosti emocionalne inteligencije djeteta. Međutim, unatoč rastućemu naglasku na činjenici "da su razvojni procesi djece sve više originalni, nepredvidivi i proturječni” (Bašić, 2011.:27) i svijesti da su "[d]ugo važeći ključni razvojno-psihološki datumi [...] korigirani” (Bašić, 2011.:27), romantično percipiranje djetinjstva kao perioda nevinosti (Pressler, 2010.) i dalje persistira u kolektivnoj svijesti društva, nastavljajući se na sliku djeteta prikazanu u Rousseauovu Emilu, u kojemu se djetinjstvo vidi kao idiličan, slobodan, sretan i bezbrižan period, a dijete kao prirodno dobro, odnosno neiskvareno (Montgomery, 2003., prema Pressler, 2010.). Iako postoje "autori koji lamentiraju nad gubitkom djetetove nevinosti i pozivaju na povratak 'nevinoga djeteta' (vidi u Postman, 1994.)” (Renold, 2005.:21), drugi pak "kritiziraju romantizaciju dječje nevinosti (koja je često oslikana u opoziciji prema 'autentičnome djetinjstvu’) i sugeriraju da diskursi nevinosti suštinski ugrožavaju djecu (Kitzinger, 1990.; Kincaid, 1994., 1998.; Giroux, 2000.). Jenny Kitzinger, na primjer, opisuje kako romantizirani pogledi na seksualno nevino dijete stigmatiziraju i isključuju one koji ne zadovoljavaju taj ideal, pa je tako bilo koje dijete koje komunicira svoju seksualnost ili ima znanja o njoj obilježeno kao 'oštećena roba' čija zaštita nije opravdana ili potrebna (Kitzinger 1990.:160-1)” (Renold, 2005.:21). Naše pozicioniranje spram toga polariteta dobro sumira teza da "kako za djecu može biti štetno dodijeliti im ista prava kao i odraslima tako prezaštićivanje s obzirom na seksualnost također može biti štetno, budući da djeci i mladima onemogućava pristup znanju i informacijama” (Moore 2013.:63, prema Moore i Reynolds, 2018.:6).

Opisani diskurs protekcionizma u periodu ranoga djetinjstva ima zadatak štititi djetetovu neseksualnost do trenutka kada ona biva, uslijed nezaustavljive provale hormona, kompromitirana u pubertetu, kada se protekcija počinje manifestirati u obliku naglašavanja prijetnji koje seksualnost mladome čovjeku donosi (osobito u vidu informiranja o spolno prenosivim bolestima). Raspravljajući tako o najčešćim roditeljskim prigovorima seksualnome obrazovanju u školama, Goldman (2008.) raščlanjuje 
roditeljsko gledište da su učenici prije perioda adolescencije premladi da bi razumjeli seks(ualnost), smatrajući da taj prigovor roditelja sadrži dvije pogreške. Prva je pogreška "transferiranja ili nametanja osobnih emocija drugoj osobi, objektu ili situaciji. Većina ljudi interpretira riječi ‘seks' i 'seksualno’ u uskome značenju seksualnoga čina i reprodukcije umjesto u širokome biološkome, psihološkome i društvenome značenju ljudske seksualnosti (Goldman i Goldman 1988.:xvii). Nekim roditeljima postaje neugodno kada se te riječi koriste zajedno s 'dijete' ili 'djeca'” (Goldman, 2008.:426). Druga se pogreška nalazi u roditeljskome stajalištu da seksualnost počinje tek s adolescencijom, no, kako autorica zaključuje, seksualnost je "kontinuirani i integralni dio postojanja i iskustva individue od začeća preko rođenja do smrti (Goldman i Goldman, 1984., 1988.; Haroian, 2000.; Blonna i Levitan, 2005.)” (Goldman, 2008.:427).

Da takvo percipiranje seksualnosti nije rezervirano isključivo za roditelje, pokazuje i kvalitativno istraživanje Goldman i Coleman (2013.), u kojemu su budući nastavnici u obrazovnome posredovanju teme seksualnosti bili skloni reprodukciji statusa quo, odnosno pretpostavljali da će tu temu u svome budućem radu u osnovnim školama tek marginalno zahvaćati, što ne čudi s obzirom na izostanak kolegija koji bi se tom temom eksplicitno bavili na nastavničkim studijima. Taj izostanak povezan je s činjenicom da nastavnički studiji seksualnost ne prepoznaju kao jedno od pitanja povezanih $s$ različitošću i društvenom pravdom, a istovremeno ju vide kao prijetnju dominantnome diskursu dobroga nastavnika, koji svoju kompetentnost dokazuje održanjem discipline (Robinson i Ferfolja, 2001.), za koju razgovor o seksualnosti može biti ugrožavajući. Ipak, smatramo da (ne)imanje kompetencija za bavljenje temom seksualne i rodne različitosti predstavlja tek dio pojašnjenja nevidljivosti te teme u odgojno-obrazovnome sustavu: "Otvaranje teme seksualnosti u školama je kompleksno i kontradiktorno. Budući da nastavnici često seksualnost, osobito lezbijsku i gej, drže moralnim i privatnim pitanjem odraslih koje se delegira prema privatnim odnosima i obitelji. [...] Obitelj se, kao moderni disciplinarni aparat države, tradicionalno promatra kao moralni čuvar seksualnoga obrazovanja djece.” (Robinson i Ferfolja, 2001.:127). Valja primijetiti da taj kontekst nedostatnih kompetencija za posredovanje seksualnosti i percipiranja seksualnosti kao teme za koju su ekskluzivno zaduženi roditelji otežava komunikaciju roditelja i stručnjaka o tome pitanju, koje prešutni društveni ugovor obvezuje da u međusobnome odnosu bez iznimke poštuju međusobnu privatnost seksualnih i rodnih identiteta. Implikacije toga smještanja seksualnosti u sferu privatnoga dalekosežne su: s jedne strane stručnjaci, osobito oni koji se ne uklapaju u normu svojim rodnim i seksualnim identitetom, zatirući tu dimenziju svoje ljudskosti nemaju mogućnost autentično pristupati pedagoškome odnosu; isto to je onemogućeno roditeljima; pritom u njihovoj međusobnoj komunikaciji neizgovorenima mogu ostati brojne činjenice koje djetetov život suštinski određuju ${ }^{3}$.

3 Primjer za potonje dvije su studije slučaja koje smo provele s dvjema LGBT obiteljima, a u kojima obje škole nisu bile upoznate sa stvarnom strukturom obitelji u kojoj dijete odrasta. 
Čini nam se bitnim ovdje naglasiti kako analizom tabua seksualnosti ne želimo implicirati nužnost eksplicitnijega izražavanja seksualnosti u odgojno-obrazovnome procesu (npr. ne želimo zagovarati uvođenje razvojno neprimjerenih sadržaja o seksualnosti ili implicirati nužnost imperativnoga raspravljanja o svojoj seksualnosti i rodu sa svima zainteresiranima), već želimo ukazati na činjenicu da je svakodnevna odgojno-obrazovna praksa već prožeta otkrivanjem heteroseksualnoga identiteta i cisrodnosti kroz niz svakodnevnih, uobičajenih komentara, koji prolaze gotovo neopaženo, odnosno kojima se ne pridaje nikakav značaj, kao što su anegdote iz privatnoga života koje se posve nesvjesno koriste u odgojno-obrazovnim interakcijama, a koje otkrivaju heteroseksualni i cisrodni identitet pojedinaca (Barale, 1994.; Crawley, 2009.; Liddle, 2009.; Mittler i Blumenthal, 1994.; sve prema Allen, 2011.; DePalma i Atkinson, 2010.), što se događa zbog kulture heteronormativnosti, odnosno "organiziranja svih obrazaca mišljenja, svijesti i uvjerenja oko pretpostavke o univerzalnoj heteroseksualnoj žudnji, ponašanju i identitetu" (Warner, 1993.:xxi-xxv, prema Allen, 2011.:81).

Sumiranjem napisanoga dolazimo do prevladavajućega diskursa seksualnosti, karakteriziranoga razvojnom linijom neseksualno rodno konformno dijete - nestabilni hiperseksualni ponekad rodno nekonformni adolescent - stabilni i diskretni rodno konformni heteroseksualni odrasli, temeljene na u Uvodu istaknutoj tezi o neodvojivome prožimanju roda i seksualnosti.

\section{Uprostorivanje seksualne $\mathrm{i}$ rodne različitosti}

Približavanjem fokusu rada u ovome poglavlju problematiziramo na koje načine prostorna kultura odgojno-obrazovne ustanove može perpetuirati ili propitivati opisano uvriježeno pristupanje seksualnoj i rodnoj različitosti, pri čemu ćemo se zbog ograničenoga opsega ovoga rada iz ranije ponuđene klasifikacije centralnih tema geografije obrazovanja autora Cook i Hemminga (2011.; ljudsko tijelo; fizička, društvena i kulturna dimenzija prostora; aktivna dimenzija prostora) usmjeriti $\mathrm{k}$ fizičkoj, društvenoj i kulturnoj dimenziji prostora, koju u postojećoj pedagogijskoj literaturi procjenjujemo najzastupljenijom (podsjetit ćemo samo na često referiranu Malaguzzijevu tezu o prostoru kao trećemu odgajatelju; Rinaldi, 2006.), no nedostatno promatranom kroz vizuru seksualnosti i rodnosti. Zbog nemogućnosti jasnoga odjeljivanja društvene i kulturne dimenzije, što prepoznaju i sami autori koji ih opisuju kao cjelinu (Cook i Hemming, 2011.), ovu ćemo temu, pregledom relevantnih teorijskih i empirijskih nalaza domaćih i stranih autora, analizirati unutar dviju potkategorija: fizičku dimenziju prostora analizirat ćemo pomoću tlocrta i uređenja prostora odgojno-obrazovne ustanove, dok će društvenu i kulturnu dimenziju reprezentirati materijali korišteni u odgojno-obrazovnome procesu. Kada god to bude moguće, pozvat ćemo se na recentna domaća empirijska istraživanja ili se eksplicitno osvrnuti na njihov nedostatak u pojedinome području. Unatoč odabranome fokusu, kako promišljanje o prostoru ne bismo predstavile apstrahiranim od međuljudskih interakcija koje prostor konstruira- 
ju, u tablici 1. donosimo integralnu razradu kategorizacije Cook i Hemminga (2011.), pri čemu smo ljudsko tijelo i aktivnu dimenziju prostora integrirale $u$ jednu cjelinu, imajući na umu načine na koje ljudsko tijelo u interakciji sa svojim okruženjem putem različitih odnosa i praksi direktno konstruira prostor. Iako je jasno da se između kategorija ne mogu povući jasne granice jer se radi o koherentnoj cjelini koja oslikava kompleksnost odgojno-obrazovnoga procesa, nesvodivu na pojedinačne varijable (pa se tako npr. (ne)obilježavanje različitih prigodnih datuma uglavnom manifestira i u uređenju prostora odgojno-obrazovne ustanove), želeći apostrofirati ideju prostora kao procesne materijalnosti, smjestile smo ga u temu ljudsko tijelo i aktivna dimenzija prostora, čime se u fokus stavljaju implicitne poruke o (ne)poželjnosti prisutnosti određenih tijela i odnosa u ustanovi koje (ne)obilježavanje datuma kao što su tjedan ponosa ili Međunarodnog dana borbe protiv nasilja nad ženama za sobom povlači).

U tablici 1. centralne teme geografije obrazovanja operacionaliziramo kroz vizuru dimenzije (ne)seksualnosti, razlomljene na potkategorije seksualne i rodne različitosti. Držimo, naime, da je dimenzije seksualne i rodne različitosti nužno razumijevati kao potkategorije unutar metakategorije (ne)seksualnosti, bez koje ni ne mogu biti shvaćene (npr. opiranje vidljivosti seksualne različitosti u ustanovi ranoga i predškolskoga odgoja ne možemo razumjeti bez konstrukta neseksualnoga djeteta koje treba biti zaštićeno od razvojno neprimjerenih sadržaja). Dimenzije seksualne i rodne različitosti međusobno se sukonstruiraju, te će također biti analizirane zajedno, iako ćemo povremeno, kada to procijenimo važnim, stavljati naglasak na primjere koji jasnije korespondiraju s jednom ili drugom dimenzijom, pri čemu oni ne predstavljaju totalitet prostorne dimenzije seksualne i rodne različitosti u odgojno-obrazovnoj ustanovi.

\section{Tablica 1.}

Analitički okvir za analizu prostorne dimenzije seksualne i rodne različitosti u odgojno-obrazovnoj ustanovi

\begin{tabular}{|c|c|c|c|}
\hline \multirow{2}{*}{\multicolumn{2}{|c|}{$\begin{array}{l}\text { Centralne teme } \\
\text { geografije obrazovanja } \\
\text { (adaptirano prema Cook } \\
\text { i Hemming, 2011.) }\end{array}$}} & \multicolumn{2}{|c|}{ Dimenzija (ne)seksualnosti $\rightarrow$ djetinjstvo - adolescencija - odraslost } \\
\hline & & $\begin{array}{c}\text { Dimenzija seksualne različitosti } \\
\text { heteronormativnost }\end{array} \rightarrow$ & $\begin{array}{c}\text { Dimenzija rodne različitosti } \rightarrow \\
\text { stereotipna rodna binarnost }\end{array}$ \\
\hline \multicolumn{2}{|c|}{$\begin{array}{l}\text { Ljudsko tijelo i aktivna } \\
\text { dimenzija prostora } \\
\text { (odnosi i prakse) }\end{array}$} & \multicolumn{2}{|c|}{$\begin{array}{c}\text { (ne)obilježavanje različitih prigodnih datuma } \\
\text { heteronormativan / rodno binaran rječnik } \\
\text { normiranje ekspresije emocionalnosti } \\
\text { normiranje ekspresije tjelesnosti }\end{array}$} \\
\hline \multirow{2}{*}{$\begin{array}{l}\text { Fizička, } \\
\text { društvena } \\
\text { i kulturna } \\
\text { dimenzija } \\
\text { prostora }\end{array}$} & $\begin{array}{l}\text { tlocrt i } \\
\text { uređenje } \\
\text { prostora }\end{array}$ & \multicolumn{2}{|c|}{$\begin{array}{l}\text { vizualna reprezentacija pluralizma seksualnih i rodnih identiteta } \\
\text { organizacija i korištenje igrališta i dvorana } \\
\text { organizacija i korištenje privatno konotiranih prostora }\end{array}$} \\
\hline & $\begin{array}{l}\text { dostupni } \\
\text { materijali }\end{array}$ & \multicolumn{2}{|c|}{$\begin{array}{c}\text { poticaji za igru i učenje } \\
\text { slikovnice, udžbenici i lektire } \\
\text { pedagoška dokumentacija i komunikacijski obrasci }\end{array}$} \\
\hline
\end{tabular}


Najopipljivija manifestacija fizičke dimenzije prostora jest njegova arhitektonska oblikovanost, odnosno tlocrtna organizacija odgojno-obrazovne ustanove i uređenje prostora, koja, pogledamo li većinu vrtićkih i školskih zgrada u Hrvatskoj, odražava funkciju nadziranja i discipliniranja seksualnosti i perpetuiranja rodne binarnosti, što možemo primijetiti u nekoliko primjera koje smo odlučile izdvojiti.

U domeni vizualne reprezentacije pluralizma seksualnih i rodnih identiteta ne postoje relevantna domaća empirijska istraživanja ${ }^{4}$, no temeljem komunikacije s odgojnoobrazovnim djelatnicima i našega boravka u različitim odgojno-obrazovnim ustanovama uočavamo stereotipne prikaze seksualnih i rodnih identiteta i uloga u uređenju prostora naših vrtića i škola. Iznenađujuće je da ni u stranome kontekstu ne postoje opsežna empirijska istraživanja fokusirana upravo na tu temu, već se skromniji empirijski podaci mogu generirati iz kvalitativnih istraživanja manjega opsega, usmjerenih na prostornu dimenziju kulture odgojno-obrazovnih ustanova (npr. istraživanja u Australiji, Kanadi i na Islandu; Ferfolja, 2007.; Grace i Wells, 2009.; Kjaran i Kristinsdóttir, 2015.), koja pokazuju da posteri mogu biti uprostoreni na različite načine pa tako Grace i Wells (2009.) ističu kako iz perspektive LGBT učenika prisutnost sadržaja o seksualnoj različitosti na zidovima, pa čak i ako moraju neprestano iznova biti postavljani na zidove škole zbog njihova uništavanja, pridonosi učeničkoj procjeni inkluzivnosti kulture škole. S druge strane, Ferfolja (2007.) temeljem rezultata svojih istraživanja upozorava da njihova sama prisutnost na zidovima škole nema osobit transformativni potencijal kako zbog činjenice da su najčešće postavljani na mjesta niske vidljivosti, primjerice na pojedine kabinete, i vrlo brzo uklanjani tako i zbog toga što njihovu vidljivost djelatnici ustanove mogu koristiti kao izgovor za nepoduzimanje dodatnih oblika bavljenja diskriminacijom i predrasudama na temelju seksualne i rodne različitosti. Osim što su takvi prikazi potencijalno štetni kada se nalaze u funkciji alibija za nepoduzimanje dodatnih pedagoških akcija, dodatna opasnost leži u stereotipnim prikazima muževnosti i ženstvenosti, odnosno perpetuiranju heteronormativnosti i hegemonijskih rodnih uloga (Kjaran i Kristinsdóttir, 2015.). Na to koliko pitanje vizualne reprezentacije različitih seksualnih i rodnih identiteta nadilazi autonomiju odgojno-obrazovne ustanove, skrenuta nam je pozornost u spomenutome istraživanju koje trenutno provodimo, a u kojemu su nam, upitani o tome bi li LGBT inkluzivnost svoje ustanove mogli demonstrirati prikazom obitelji s roditeljima istoga spola na zidovima ustanove, sudionici u jednoj ustanovi naglasili kako odluku o plakatima koji mogu biti postavljeni na zidove ustanove donosi nadležno ministarstvo ${ }^{5}$. Tim nam se više, $s$ obzirom na prevladavajuću kulturu heteronormativnosti,

${ }^{4}$ Vizualna reprezentacija seksualne i rodne različitosti u školama bila je jedna od tema serije fokus-grupa koje smo u sklopu istraživačkoga projekta LGBT (ne)vidljivost u školi: perspektiva odgojno-obrazovnih djelatnika provele u nekoliko hrvatskih srednjih škola, a čiji su podaci trenutno u procesu analize.

5 Ne želeći ulaziti u dublju digresiju, držimo nužnim ukazati na povezanost teme kojom se bavimo $s$ razinom profesionalne autonomije nastavnika, koja čini jedan od gradivnih elemenata kulture škole, za čiji je autentičan razvoj pozicioniranje nastavnika kao izvršitelja naputaka dobivenih odozgo uglavnom kontraproduktivno. 
čini važnim istaknuti da je vidljivosti i uključenosti LGBT obitelji moguće pridonijeti i direktnije, uprostorivanjem datuma koji su relevantni za povijest političke borbe za prava LGBT zajednice, kao što je Tjedan ponosa, za koji nam se čini kako je trenutno smješten u nul-kurikulum većine naših odgojno-obrazovnih ustanova. $\mathrm{Na}$ tragu geografa obrazovanja koji sustavno ističu ulogu prostora u konstituiranju seksualnoga identiteta, ukazujemo na potencijale jednostavnoga označavanja posvećenosti ustanove i njenih djelatnika (England, 1999.) političkoj borbi za prava seksualnih i rodnih manjina (pri čemu, zbog njihove specifične uloge u oblikovanju kulture ustanove, primarno odgovornima držimo pedagoge i psihologe), što se na primjer može napraviti stavljanjem jednostavnoga obilježja (trokuta, zastavice i sl.) na vrata svoga ureda.

Druga točka koju je u sklopu tlocrta i uređenja prostora moguće analizirati jest način na koji se organiziraju i koriste igrališta i dvorane, a koji, osim proklamirane tjelesnozdravstvene funkcije, ima implicitnu ulogu perpetuiranja različitih rodnih stereotipa i istovremenoga nadziranja seksualnosti. Paechter i Clark (2007.) daju pregled istraživanja koja ističu važnost igrališta u konstrukciji rodnoga identiteta učenika. Ta je važnost izvrsno sumirana u viđenju Epstein i sur. (2001.:158, prema Paechter i Clark, 2007.:320), koji kažu da "geografija i prostorna organizacija igrališta govore rodnim jezikom moći”, pri čemu je prostor igrališta i dvorana dominantno korišten u svrhu konstrukcije maskuliniteta, bivajući namijenjen grupnim sportovima tradicionalno rezerviranima za dječake (prije svega nogometu). Raspravljajući o tome problemu međusobno i sa studentima u nastavi kolegija usmjerenoga na teme roda i seksualnosti, iz sabranih smo iskustava primijetile obrazac organizacije nastave tzv. tjelesnog $\mathrm{u} \mathrm{hr}$ vatskim školama, koji je bitno različit za djevojčice i dječake, što je potvrđeno i istraživanjem koje je na uzorku od 314 učenika i učenica osmih razreda osnovnih škola u Osijeku (Tomac, Šumanović i Rastovski, 2013.) pokazalo da dječaci nastavu Tjelesne i zdravstvene kulture vole više i drže zanimljivijom od djevojčica, što autori povezuju $s$ rodno diversificiranim programom toga predmeta u višim razredima osnovne škole i neadekvatnom pripremljenošću dominantno muških nastavnika za rad s djevojčicama. I strani autori (npr. Martínez-Andrés i sur., 2017.) upozoravaju na prostornu dominaciju dječaka, za koju se kao mogući uzroci ponovno navode rodno specifičan odabir aktivnosti podržavan ulogom nastavnika, koji su skloni velik dio prostora osigurati za kompetitivne igre kao što je nogomet, koji dječaci tradicionalno preferiraju (i iz nje isključuju djevojčice i manje spretne dječake). Tu za djevojčice diskriminirajuću arhitekturu školskih igrališta (Hart, 2002.; Paechter i Clark, 2007.; Dyment i O’Connell, 2013.; sve prema Snow i sur., 2019.) pronicljiv pedagog može lako uočiti te nastavnicima biti kritički prijatelj u procesu njihove transformacije, no od inzistiranja na rodnome paritetu, odnosno ravnomjernoj distribuciji prostora između dječaka i djevojčica, važnijim smatramo njegov rad na dekonstrukciji tradicionalnih rodnih stereotipa koji djeci, neovisno o njihovim individualnim afinitetima, onemogućavaju sudjelovanje u rodno netipičnim aktivnostima (Paechter i Clark, 2007. podrobno analiziraju prepreke s kojima se suočavaju djevojčice koje žele igrati nogomet). 
Treći primjer unutar ove kategorije jest pitanje organizacije i korištenja privatno konotiranih prostora. Pišući o ustanovama ranoga i predškolskoga odgoja, Slunjski i sur. (2015.), izvan konteksta seksualnosti, upozoravaju na neprikladno korištenje staklenih površina između hodnika i dječjih toaleta, koje narušava privatnost djece. Čini nam se da se ostakljivanje toaleta u dječjim vrtićima, kao i bojazan odraslih glede različitih prostornih rješenja koja djeci omogućavaju osamljivanje ili čak sakrivanje od direktnoga pogleda odraslih, može, iako razumijemo njegovu zaštitnu funkciju, povezati i sa strahom od prerane manifestacije seksualnosti i ranije spomenutim diskursom protekcionizma koji ima zadatak štititi djetetovu neseksualnost što god je duže moguće. To pitanje postaje daleko važnijim prelaskom iz vrtića u školu, kada se u sve restriktivnijoj organizaciji prostora škola očituje već spomenuta bojazan od eksplozije seksualnosti mladih, čija tijela valja kontrolirati kako bi se preveniralo javljanje bilo kakvoga seksualnog interesa za suučenike, što se čini odvajanjem toaleta, presvlačenjem u odvojenim garderobama i odvojenom nastavom tjelesnog i zdravstvenog odgoja (Paechter, 2004.), što za LGBT učenike može predstavljati osobit izazov jer samom svojom prisutnošću ugrožavaju percipiranu zaštićenost i rodnu i seksualnu homogenost tih prostora (Fields i Payne, 2016.).

Na mikrorazini geografije obrazovanja, razini dostupnih materijala, krenut ćemo fokusirajući se na poticaje za igru i učenje $e^{6}$. Uvažavajući utjecaj industrije igračaka i izrazito opstojne mehanizme rodne socijalizacije na oblikovanje stvarnosti djece, smatramo važnim istaknuti rezultate istraživanja koji ukazuju na to da djeca vrlo rano počinju preferirati igračke koje se smatraju prikladnima za njihov biološki spol (Weisgram, Fulcher i Dinella, 2014.), pri čemu se djevojčice usmjeravaju na lutke i igračke vezane za domaćinstvo, a dječaci na sportsku opremu, alate i vozila (Nelson, 2005.; Pomerleau, Bolduc, Malcuit i Cossette; 1990.; sve prema Boekee i Brown, 2015.). Dugoročno gledano, podržavanje takvih stereotipnih preferencija dječake i djevojčice vodi razvoju različitih interesa i vještina (vidi u Granger i sur., 2017.), odnosno priprema ih za preuzimanje stereotipne ženske odnosno muške uloge u odrasloj dobi, što može biti porobljujuće za oba spola. Te dobro poznate činjenice ne treba diskreditirati kao suvišne, na što nas sve intenzivnije upozoravaju recentna kvalitativna empirijska istraživanja koja, usmjeravajući se na odgajateljevu medijaciju igre, ukazuju na njihovu sklonost perpetuiranju tradicionalnih rodnih uloga, čak i u situacijama kada se djeca tome suprotstavljaju (vidjeti npr. Meland i Kaltvedt, 2019.). Stoga se geografija prostora u ovoj dimenziji ne može iscrpiti u analizi (ne)stereotipnosti samih poticaja za igru i uče-

${ }^{6}$ Zbog Reggio-koncepcijom inspiriranoga trenda uvođenja multisenzoričnih elemenata u prostorno-materijalno okruženje vrtića (Edwards i sur., 1998.; Thornton i Brunton, 2007.; sve prema Slunjski i sur., 2015.), u kojemu naglasak biva stavljen na za vrtić netipične materijale koji podržavaju dječje interese i znatiželju, ova se analiza ne fokusira isključivo na igračke, koje impliciraju unaprijed oblikovane objekte s jasno zadanom funkcijom, već na različite materijale koji mogu poslužiti kao poticaji za igru i učenje, no koji, usprkos svojoj nedovršenosti i otvorenosti različitim načinima korištenja i konstruiranja, u interakciji između odgajatelja i djeteta, jednako kao igračke, mogu (ili ne moraju) biti stereotipno upotrebljavani. 
nje, već se treba usmjeriti na to podržavaju li ti poticaji interese djeteta ili su u službi potreba odraslih, koja je nerijetko neosviještena - zanimljiva studija autorice Lynch (2015.), usmjerena na percepciju rodno determinirane igre u vrtićima, pokazala je da pojedini odgajatelji centre aktivnosti ne promatraju kao potencijalno rodno neutralne, već su u njihovu oblikovanju promišljali o njihovoj većoj primjerenosti za dječake ili djevojčice, bivajući iznenađeni ukoliko su sama djeca prešla njihove zamišljene granice. Iako konstatira da je poučavanje koje propituje dominantne načine razumijevanja roda, djece i njihova učenja u kontekstu ustanova ranoga i predškolskoga odgoja zahtjevno, Blaise (2005.) takvu praksu vidi kao sastavni dio profesionalne odgovornosti odgojno-obrazovnih djelatnika koji su posvećeni jednakosti i društvenoj pravdi.

Sljedeću kategoriju analize čine slikovnice, udžbenici i lektire kao materijalni elementi prostora. Pritom se nećemo usmjeriti na u hrvatskoj znanosti istraženu temu posredovanja rodnih stereotipa (Baranović, 2000.; Kolega, Ramljak i Belamarić, 2011.), odnosno LGBT tema (Brumen, 2012.) u slikovnicama i udžbenicima različitih predmeta, već ćemo naglasak staviti na manje spominjan problem discipliniranja i normiranja seksualnosti u odgojno-obrazovnim ustanovama, koje se na eksplicitan način očituje u postizanju konsenzusa oko literature kojoj djeca, ovisno o dobi, mogu i trebaju biti izložena. "Općenito, knjige na policama [školske knjižnice] odražavaju sadržaj školskoga kurikuluma koji prioritizira um i marginalizira tijelo (Paechter, 2004.). To znači da su u većini školskih knjižnica eksplicitni tekstovi o seksualnosti smatrani neprikladnima." (Allen, 2013.:69) Ta je praksa cenzuriranja neprikladne literature pod izlikom dobne primjerenosti, inače dobro dokumentirana u stranoj (npr. Wickens, 2010.), ali i domaćoj literaturi (npr. Širac, 2017. analizira čišćenje lektirnih naslova u srednjoj školi od bilo kakvih eksplicitnih seksualnih sadržaja), osobito problematična u periodu kada su mladi putem medija sa svih strana izloženi seksualno eksplicitnim sadržajima, no bez adekvatnoga pedagoškoga posredovanja (Wickens, 2010.). Međutim, dodatna dimenzija problematičnosti cenzure očituje se u njenome proširivanju na šira pitanja društvene pravde koja se povezuju sa seksualnošću, kao što su homofobija i drugi oblici opresije osoba koje svojim identitetima propituju seksualnu i rodnu normu, čije se spominjanje to neprimjerenijim smatra što je razina odgojnoobrazovnoga sustava niža. Postoje, međutim, istraživanja koja pokazuju kako je teme rodnoga konformiranja i LGBT identiteta moguće pedagoški konstruktivno zahvatiti već u osnovnoj školi te čak smjestiti u širi kontekst društvene pravde, odnosno diskriminacije i opresije općenito; da djeca na njih jako dobro reagiraju, pri čemu sami materijali, njihova vidljivost u prostoru škole i aktivno zahvaćanje u pedagoškome odnosu postaju antibullying politika (Ryan, Patraw i Bednar, 2013.). Smještanje seksualne i rodne različitosti u širi kontekst društvene pravde čini nam se pristupom koji je primjeren za bavljenje tim temama i u ustanovama ranoga i predškolskoga odgoja - primjerice, prezentiranje slikovnice o LGBT obiteljima ne treba biti promatrano kao plasiranje teme o homoseksualnosti za to razvojno nepripremljenoj djeci, već kao poučavanje o različitosti obitelji općenito (strategija koju opisuje jedan nastavnik u 
istraživanju DePalme, 2016.). Štoviše, takvo pristupanje ne držimo nekom kompromisnom strategijom zaštite od mogućih napada roditelja ili nadležnih tijela (Martino i Cumming-Potvin, 2011. pišu o "tiraniji roditeljskoga nadzora"), već deesencijalističkim pristupom ${ }^{7}$ poučavanju različitosti, koji ističe važnost pomicanja fokusa s pojedine dimenzije identiteta na ukupnost naših bića i društvenoga konteksta u kojemu živimo. Kao i kod prethodnih dimenzija, i ovdje je važno usmjeriti se na način pedagoškoga posredovanja tema seksualne i rodne različitosti u materijalima korištenima u odgojno-obrazovnome prostoru i procesu: Dinkins i Englert (2015.:403) upozoravaju na važnost nastavnikova kritičkoga pristupanja LGBT literaturi i njegove svijesti da "[s]amo uključivanje LGBTQ tekstova u kurikulum ne znači i sustavno apostrofiranje prevladavajućega heteronormativnog razrednog okružja.”

Posljednja jedinica analize, pedagoška dokumentacija ${ }^{8}$ i komunikacijski obrasci, poveziva je s ranije analiziranom vizualnom reprezentacijom pluralizma seksualnih i rodnih identiteta, odnosno heteronormativnosti i homofobije duboko ukorijenjenih u kulturu odgojno-obrazovnih ustanova (na što ukazuju i različita domaća empirijska istraživanja, primjerice Bagić, 2011.; Bijelić i Hodžić, 2013.; Bovan i Širinić, 2016.): "Heteroseksualno ponašanje i jezik integrirani su i normalizirani unutar kulture škole u toj mjeri da su postali prirodno, a često i 'neutralno', školsko okruženje ili kultura. Stvari kao što su muško-ženski iskazi privlačnosti i naklonosti, razgovori o vezama između partnera suprotnoga spola na hodnicima i u učionici, školski plesovi, maturalne večere, anti-gej šale i uvrede te zlostavljanje gej učenika i učenica ne promatraju se kao 'eksplicitno heteroseksualni'. Te se aktivnosti uglavnom percipiraju tek kao prirodno školsko okruženje i kultura mladih. Ipak, postoji niz načina na koje su norma heteroseksualnosti i preskriptivnih ponašanja za žene i muškarce koje ona podupire konstruirane i održavane pomoću organiziranih i spontanih interakcija između učenika te učenika i djelatnika.” (Miceli, 2011.:439). Kako se ovdje fokusiramo na materijale koji se u odgojno-obrazovnome procesu koriste, spomenutu heteronormativnost uočavamo u presumpciji heteroseksualnosti u komunikaciji s dvoroditeljskim obiteljima ${ }^{9}$, pri čemu se samo ostvarenje roditeljstva uzima kao dostatan dokaz toga seksualnog identiteta, a sigurne smo da bi pažljiva analiza pedagoške dokumentacije i komunikacijskih obrazaca rezultirala još pokojim primjerom neinkluzivnosti tih materijala. Kao moguće polje analize nametnula nam se mjera u kojoj materijali na-

${ }^{7}$ Drugačije rečeno, umjesto promatranja LGBT obitelji kao one koja je suštinski određena upravo roditeljskim seksualnim i rodnim identitetom, taj identitet promatramo tek kao jedno obilježje te obitelji.

8

8 Pod pedagoškom dokumentacijom u ovome radu podrazumijevamo različite oblike pisanoga praćenja i arhiviranja različitih segmenata odgojno-obrazovnoga procesa, kao što su imenici i dnevnici u školi te pedagoška dokumentacija odgojno-obrazovne skupine i imenici djece u ustanovama ranoga i predškolskoga odgoja.

9 Primjerice, Pravilnik o pedagoškoj dokumentaciji i evidenciji te javnim ispravama u školskim ustanovama (2017.) navodi da se u razredne i matične knjige upisuje "ime i prezime majke i oca odnosno skrbnika” (vidi npr. čl. 8, točka 5). 
mijenjeni pedagoškome obrazovanju roditelja koje ustanova nudi roditeljima perpetuiraju tradicionalnu distribuciju rodnih/obiteljskih uloga, prepoznajući majku kao onu dominantno zaduženu i za roditeljevanje i za komunikaciju s odgojno-obrazovnom ustanovom. U manjku opsežnijih domaćih koja bi se bavila tom temom, relevantno je inozemno istraživanje koje je provela Sunderland (2006.), a koje je pokazalo da iako su se u skladu s društvenim očekivanjima časopisi specijalizirani za roditeljevanje počeli obraćati i majkama i očevima te reprezentirati obje uloge, oni na sadržajnoj razini nisu promovirali dijeljeno, ravnopravno roditeljevanje pa čak ni bili slobodni od rodnih stereotipa. Drugim riječima, eksplicitno obraćanje ocu tek je kozmetička promjena ako roditeljevanje u samim materijalima nije doista prezentirano kao uloga koja nije suštinski određena biološkim spolom.

\section{Zaključak}

Poduzeta razmatranja, koja u domaćoj znanosti predstavljaju tek otvaranje teme uprostorivanja seksualne i rodne različitosti u odgojno-obrazovnim ustanovama, vidimo kao poziv na ekstenzivniju analizu, kao i na dekolonizaciju i reinhabitaciju (Gruenewald, 2003.) seksualne i rodne različitosti u odgojno-obrazovnome prostoru, odnosno kao poziv na intenzivnije zaživljavanje prostora kao pedagoškoga projekta (Rinaldi, 2006.). Sljedećim nužnim korakom držimo daljnju operacionalizaciju dimenzije ljudskoga tijela i aktivne dimenzije prostora, što je zbog njene naglašene interaktivne i dijalektičke prirode teorijski izazovniji poduhvat od operacionalizacije fizičke, društvene i kulturne dimenzije prostora, kao i provođenje serije empirijskih istraživanja o različitim aspektima iznesene problematike, koje je značajnije tim više što smo pregledom literature naišle na manjak relevantnih empirijskih podataka prikupljenih u hrvatskome kontekstu. Ta istraživanja nikako ne bi smjela imati isključivo deskriptivni karakter, već bi se u duhu transformativno orijentirane kvalitativne metodologije njihovo poduzimanje moglo iskoristiti kao poticaj za propitivanje statusa quo prostorne dimenzije odgojno-obrazovnoga procesa. 


\section{Literatura}

1. Allen, L. (2013). Behind the bike sheds: sexual geographies of schooling. British Journal of Sociology of Education, 34 (1): 56-75.

2. Allen, L. (2011). 'Undoing' the self: should heterosexual teachers 'come out' in the university classroom?. Pedagogy, Culture \& Society, 19 (1): 79-95.

3. Bagić, D. (Ur.) (2011). Odgoja li škola dobre gradane? Studija o političckoj socijalizaciji hrvatskih srednjoškolaca. Zagreb: GONG.

4. Baranović, B. (2000). "Slika” žene u udžbenicima književnosti. Zagreb: Institut za društvena istraživanja u Zagrebu.

5. Bartulović, M. and Kušević, B. (2019). Understanding LGBTIQ parents' transformative potential in educational context. Intercultural Education. https://doi. org/10.1080/14675986.2019.1673991.

6. Bartulović, M. and Kušević, B. (2017). Queering the White Picket Fence: a social justice take on heteronormative parenting. Multicultural Education Review, 9 (1): 11-29.

7. Bašić, S. (2011). (Nova) slika djeteta u pedagogiji djetinjstva, u: Maleš, D. (Ur.). Nove paradigme ranoga odgoja. Zagreb: Filozofski fakultet Sveučilišta u Zagrebu, Zavod za pedagogiju, 19-37.

8. Bijelić, N. and Hodžić, A. (2013). Heteronormativity in secondary schools in Zagreb: Young men wearing make-up, kissing and walking proudly. Družboslovne razprave, $73:$ 43-60.

9. Blaise, M. (2005). Playing it Straight. Uncovering Gender Discourses in the Early Childhood Classroom. New York: Routledge.

10. Boekee, K. and Brown, T. (2015). Gender Stereotypes of Children's Toys: Investigating the Perspectives of Adults Who Have and Do Not Have Children. Journal of Occupational Therapy, Schools, \& Early Intervention, 8 (1): 97-107.

11. Bovan, K. i Širinić, D. (2016). (Ne)demokratski stavovi maturanata u Hrvatskoj - prisutnost i odrednice, u: Kovačić, M. i Horvat M. (Ur.). Od podanika do gradana: razvoj gradanske kompetencije mladih. Zagreb: Institut za društvena istraživanja u Zagrebu, GONG, 73-89.

12. Brumen, S. (2012). LGBT tematika u udžbenicima za srednju i osnovnu školu. Zagreb: Lezbijska udruga Kontra.

13. Cook, V. A. and Hemming, P. J. (2011). Education spaces: embodied dimensions and dynamics. Social \& Cultural Geography, 12 (1): 1-8.

14. DePalma, R. (2016). Gay penguins, sissy ducklings... and beyond? Exploring gender and sexuality diversity through children's literature. Discourse: Studies in the Cultural Politics of Education, 37 (6): 828-845.

15. DePalma, R. and Atkinson, E. (2010). The nature of institutional heteronormativity in primary schools and practice-based responses. Teaching and Teacher Education, 26 (8): 1669-1676.

16. Dinkins, E. G. and Englert, P. (2015). LGBTQ literature in middle school classrooms: possibilities for challenging heteronormative environments. Sex Education, 15 (4): 392-405. 
17. England, K. (1999). Sexing Geography, Teaching Sexualities. Journal of Geography in Higher Education, 23 (1): 94-101.

18. Ferfolja, T. (2007). Schooling cultures: institutionalizing heteronormativity and heterosexism. International Journal of Inclusive Education, 11 (2): 147-162.

19. Fields, J. and Payne, E. (2016). Editorial introduction: Gender and sexuality taking up space in schooling. Sex Education, 16 (1): 1-7.

20. Freire, P. (2002). Pedagogija obespravljenih. Zagreb: ODRAZ - Održivi razvoj zajednice.

21. Goldman, J. D. G. (2008). Responding to parental objections to school sexuality education: a selection of 12 objections. Sex Education, 8 (4): 415-438.

22. Goldman, J. D. G. and Coleman, S. J. (2013). Primary school puberty/sexuality education: student-teachers' past learning, present professional education, and intention to teach these subjects. Sex Education, 13 (3): 276-290.

23. Grace, A. P. and Wells, K. (2009). Gay and bisexual male youth as educator activists and cultural workers: the queer critical praxis of three Canadian highschool students. International Journal of Inclusive Education, 13 (1): 23-44.

24. Granger, K. L.; Hanish, L. D.; Kornienko, O.; Bradley, R. H. (2017). Preschool Teachers' Facilitation of Gender-Typed and Gender-Neutral Activities during Free Play. Sex Roles, 76 (7-8): 498-510.

25. Gruenewald, D. A. (2003). The Best of Both Worlds: A Critical Pedagogy of Place. Educational Researcher, 32 (4): 3-12.

26. Gulson, K. N. and Symes, C. (2007). Knowing one's place: space, theory, education. Critical Studies in Education, 48 (1): 97-110.

27. Kjaran, J. I. and Kristinsdóttir, G. (2015). Schooling sexualities and gendered bodies. Experiences of LGBT students in Icelandic upper secondary schools. International Journal of Inclusive Education, 19 (9): 978-993.

28. Kolega, M.; Ramljak, O. i Belamarić, J. (2011). Što ću biti kad odrastem? Analiza zanimanja u dječjim slikovnicama. Magistra Iadertina, 6 (1): 25-35.

29. Löw, M. (2016). The Sociology of Space: Materiality, Social Structures, and Action. New York: Palgrave Macmillan.

30. Lynch, M. (2015). Guys and dolls: a qualitative study of teachers' views of gendered play in kindergarten. Early Childhood Development and Care, 185 (5): 679-693.

31. Martínez-Andrés, M.; Bartolomé-Gutiérrez, R.; Rodríguez-Martín, B.; PardoGuijarro, M. J.; Martínez-Vizcaíno, V. (2017). "Football is a boys' game”: children's perceptions about barriers for physical activity during recess time. International Journal of Qualitative Studies on Health and Well-being, 12 (1): 1-9.

32. Martino, W. and Cumming-Potvin, W. (2011). "They Didn't Have Out There Gay Parents - They Just Looked Like Normal Regular Parents": Investigating Teachers' Approaches to Addressing Same-Sex Parenting and Non-normative Sexuality in the Elementary School Classroom. Curriculum Inquiry, 41 (4): 480-501. 
33. Meland, A. T. and Kaltvedt, E. H. (2019). Tracking gender in kindergarten. Early Childhood Development and Care, 189 (1): 94-103.

34. Miceli, M. S. (2011). Schools and the social control of sexuality, in: Seidman, S.; Fischer, N. and Meeks, C. (Eds.). Introducing the New Sexuality Studies. Second Edition. Oxon: Routledge, 438-445.

35. Moore, A. and Reynolds, P. (2018). Childhood and Sexuality. Contemporary Issues and Debates. London: Palgrave Macmillan.

36. Paechter, C. (2004). "Mens sana in Corpore Samo": Cartesian dualism and the marginalisation of sex education. Discourse: studies in the cultural politics of education, 25 (3): 309-320.

37. Paechter, C. and Clark, S. (2007). Learning gender in primary school playgrounds: findings from the Tomboy Identities Study. Pedagogy, Culture \& Society, 15 (3): 317-331.

38. Pravilnik o pedagoškoj dokumentaciji i evidenciji te javnim ispravama $u$ školskim ustanovama, Narodne novine 47/2017.

39. Pressler, S. J. (2010). Construction of childhood: the building blocks, in: Kassem, D.; Murphy, L. and Taylor, E. (Eds.). Key Issues in Childhood and Youth Studies. Oxon: Routledge, 14-26.

40. Ryan, C. L.; Patraw, J. M. and Bednar, M. (2013). Discussing Princess Boys and Pregnant Men: Teaching About Gender Diversity and Transgender Experiences Within an Elementary School Curriculum. Journal of LGBT Youth, 10 (1-2): 83-105.

41. Renold (2005). Girls, Boys and Junior Sexualities. Exploring children's gender and sexual relations in the primary school. Oxon: Routledge Falmer.

42. Rinaldi, C. (2006). In Dialogue with Reggio Emilia. Listening, researching and learning. London: Routledge.

43. Robinson, K. H. and Ferfolja, T. (2001). 'What are We Doing this For?' Dealing with Lesbian and Gay Issues in Teacher Education. British Journal of Sociology of Education, 22 (1): 121-133.

44. Robinson, K. H.; Smith, E. and Davies, C. (2017). Responsibilities, tensions and ways forward: parents' perspectives on children's sexuality education. Sex Education, 17 (3): 333-347.

45. Shapiro, S. B. (2015). Pedagogy and the Politics of the Body: A Critical Praxis. New York: Routledge.

46. Sielert, U. (2008). Uvod u seksualnu pedagogiju. Zagreb: Educa.

47. Slunjski, E. i sur. (2015). Izvan okvira. Kvalitativni iskoraci u shvaćanju i oblikovanju predškolskog kurikuluma. Zagreb: Element.

48. Snow, D.; Bundy, A.; Tranter, P.; Wyver, S.; Naughton, G.; Ragen, J.; Engelen, L. (2019). Girl's perspectives on the ideal school playground experience: an exploratory study of four Australian primary schools. Children's Geographies, 17 (2): $148-161$.

49. Sunderland, J. (2006). 'Parenting' or 'mothering'? The case of modern childcare magazines. Discourse \& Society, 17 (4): 503-527. 
50. Širac, L. (2017). Cenzura dječje književnosti i lektirnih naslova. Jat: časopis studenata kroatistike, 1 (3): 10-24.

51. Taylor, C. (2009). Towards a geography of education. Oxford Review of Education, 35 (5): 651-669.

52. Tomac, Z.; Šumanović, M. i Rastovski, D. (2013). Tjelesna i zdravstvena kultura iz perspektive učenika osmih razreda osnovne škole. Život i škola: časopis za teoriju i praksu odgoja i obrazovanja, 59 (29): 463-477.

53. Weisgram, E. S.; Fulcher, M. and Dinella, L. M. (2014). Pink gives girls permission: Exploring the roles of explicit gender labels and gender-typed colors on preschool children's toy preferences. Journal of Applied Developmental Psychology, 35 (5): 401-409.

54. Wickens, C. (2010). The Denial of Sexuality and the Power of Censorship, in: Cannella Gaile, S. and Diaz Soto, L. (Eds.). Childhoods. A Handbook. New York: Peter Lang Publishing, 281-290.

55. Willis, A. S. (2017). Querring Place: Using the Classroom to Describe the World, in: Shannon, D. and Galle, J. (Eds.). Interdisciplinary Approaches to Pedagogy and Place-Based Education. Cham: Palgrave Macmillan, 135-145. 
Pregledni rad

\title{
Spatialization of Sexual and Gender Diversity in Educational Institutions
}

\author{
Marija Bartulović \\ Faculty of Humanities and Social Sciences, Univesity of Zagreb, Croatia \\ e-mail: mbartulo@ffzg.hr \\ Barbara Kušević \\ Faculty of Humanities and Social Sciences, Univesity of Zagreb, Croatia \\ e-mail: bkusevic@ffzg.hr
}

\begin{abstract}
This paper analyses different modalities of sexual and gender diversity mediation through physical environment. In the first part of the paper the terminological framework is discussed through the concepts of geography of education and sexual and gender diversity. The second part locates sexuality and gender in the context of educational institution and analyses different aspects of their spatialization, emphasizing the ground plan and material arrangements of educational institutions, and the materials used in pedagogical interactions. The concluding part of the paper addresses further possibilities of researching this topic.
\end{abstract}

Key words: geography of education, physical (pre)school environment, heteronormativity, gender binary, educational inclusivity. 